\title{
Translator's Preface
}

Although there are many useful books that describe Dante's development as a social being, a poet, and a citizen against the background of his times, none of them seem to me to surpass the late Michele Barbi's account for compactness, unity, and scholarly combination of the best of the early commentators with the findings of modern research.

Michele Barbi's life came to an end in I94I when he was seventy-four years old; it had been a life of extraordinary productivity and assiduous devotion to Italian literature and philology, with special emphasis upon Dante. The present work first appeared in the Enciclopedia Italiana in 1931 and was later published in book form as Dante: Vita, opere e fortuna in Florence in 1933. Barbi's indefatigable and painstaking work on the texts of the Vita Nuova, the Canzoniere, and the Divina Commedia, his interest in problems relating to Dante's life and work, his positions as general editor of the Italian edition of Dante's works, which appeared in 192I, as director of the Bolletino della Società Dantesca Italiana from I893 to 1905, and founder of Studi Danteschi (1920), qualified him preëminently to be Dante's most recent, authoritative Italian biographer.

It cannot be denied that Dante's genius demands constant elucidation. If a reason was needed for making known another life of Dante, as Barbi has done, it would be found in the provocative complexity of Dante's own personality as it 


\section{vi TRANSLATOR'S PREFACE}

is expressed in his work. A biography which enables us to consider as a whole the life of one whom T. S. Eliot calls "the most universal of poets in the modern languages" serves a real purpose and satisfies a real need. For Dante, like all great poets, supplies in small compass an encyclopedia of the learning of his time. The greater the poet, the greater the need for describing his greatness, his importance linguistically, politically, theologically, historically, and poetically. All this Barbi has done for us.

It is especially valuable that English-speaking readers should have made available to them a life of Dante by a writer who was himself an Italian and whose point of view is so entirely sympathetic with the greatest of Italian poets. It is in this mixture of natural sympathy for Dante's aims with sober judgment and scholarly care that the value of Barbi's biography resides.

Dante's works themselves form a kind of biography. The Vita Nuova, the Convivio, the De Vulgari Eloquentia, the Canzoniere, the Epistles, the Eclogues, and the Commedia are all memorable in one way or another for poignant passages in which Dante records his anxieties, his frustrations, and his hopes, together with names of places and persons he has known. Barbi himself has given tacit evidence of this. The reader who has familiarized himself with Dante will find many reminiscences of the poet's own language in that of Barbi. For this reason I have taken few liberties with the translation. Barbi's formal, scholarly Italian I have rendered as closely as possible, breaking sentences only when their great length would make them involved and confusing in translation. By so doing I have hopes that the reader may feel something of the harmony that existed between the biographer and his subject. 
TRANSLATOR'S PREFACE vii

I gratefully acknowledge a great debt to Professor Elio Gianturco, of the University of Pennsylvania, for his many suggestions for improving the style and accuracy of the text.

P. G. R. 
